

\section{Entre o Sagrado e o Fantástico: as (des)construções imagéticas em Noé1}

Between the Sacred and the Fantastic: the imagistic (un)constructions in Noah

\section{Fabiana Rodrigues ${ }^{2}$}

\section{Resumo}

O presente artigo tem como objetivo analisar a relação do elemento Fantástico com a temática do Sagrado, presentes no filme Noé (Darren Aronofsky, 2014). O Sagrado, aqui, deve ser entendido literalmente como a história bíblica de Noé, que começa no Gênesis, bem antes da conhecida reunião dos animais que antecede o dilúvio divino. Desta forma, para além do contexto bíblico, há o elemento Fantástico, no filme, que vem a transformar o elemento Sagrado da narrativa em somente um pano de fundo para o desencadeamento de ações ditas do gênero Fantástico.

\section{Palavras-chave}

Fantástico; sagrado;

desconstrução; descrença.

\section{Abstract}

This article aims to analyze the relationship between the Fantastic element and the theme of the Sacred in the movie Noah (Darren Aronofsky, 2014). The Sacred, here, should be literally understood as the biblical story of Noah in Genesis, that begins far before the known meeting of animals prior the divine flood. Thus, apart from the biblical context, there is the Fantastic element in the movie that transforms the Holy element of the narrative in only a backdrop for the trigger of actions of the Fantastic genre.

\section{Keywords}

Fantastic; sacred; deconstruction; disbelief 


\section{Noé - Breve panorama bíblico}

A história bíblica de Noé inicia-se, de acordo com o livro do Gênesis, com Deus observando o mau comportamento da humanidade. Assim, decide inundar a Terra e destruir toda forma de vida. Contudo, Deus encontra um homem bom, chamado Noé, virtuoso e inocente em seu tempo. Diante desta bondade e virtuosidade, fica decidido que Noé iria preceder uma nova linhagem do homem. Ou seja, não seria exterminado durante o fim do mundo. Deus disse a Noé que construísse uma arca e levasse com ele a esposa, seus filhos Shem, Ham e Japheth, e suas esposas. E, de todas as espécies de seres vivos existentes, deveriam ser levados dois exemplares, macho e fêmea, a fim de que perpetuassem as espécies. Também, para que o sustento fosse garantido, alimentos deveriam ser armazenados.

Após Noé, sua família e os animais selecionados embarcarem, a chuva começa a cair na Terra por quarenta dias e quarenta noites. A inundação cobre tudo, desde as mais altas montanhas até a mínima vegetação rasteira, e, assim, todas as criaturas acabam morrendo. Porém, Noé e todos que estavam com ele sobrevivem. Após quarenta noites e quarenta dias, a chuva cessa, mas a água permanece sobre a Terra por mais um tempo. Com o passar dos dias, Deus se lembra de Noé e dos que estavam com ele na arca, e faz passar um vento que baixa as águas. A arca descansa sobre o Monte Ararate e, com a diminuição das águas, os topos das montanhas voltam a aparecer. Noé envia alguns animais voadores aos céus, como pombas e corvos, para que lhe tragam alguma informação sobre o movimento das águas. Em uma de suas últimas tentativas, ele descobre que a água baixou em outros lugares, e assim sua arca pode finalmente atracar em

19 PORTO ALEGRE | v. 19 | n. 32 | 2014 | pp. 18-25 Sessões do Imaginário

\section{ASSISTA AO VÍDEO}

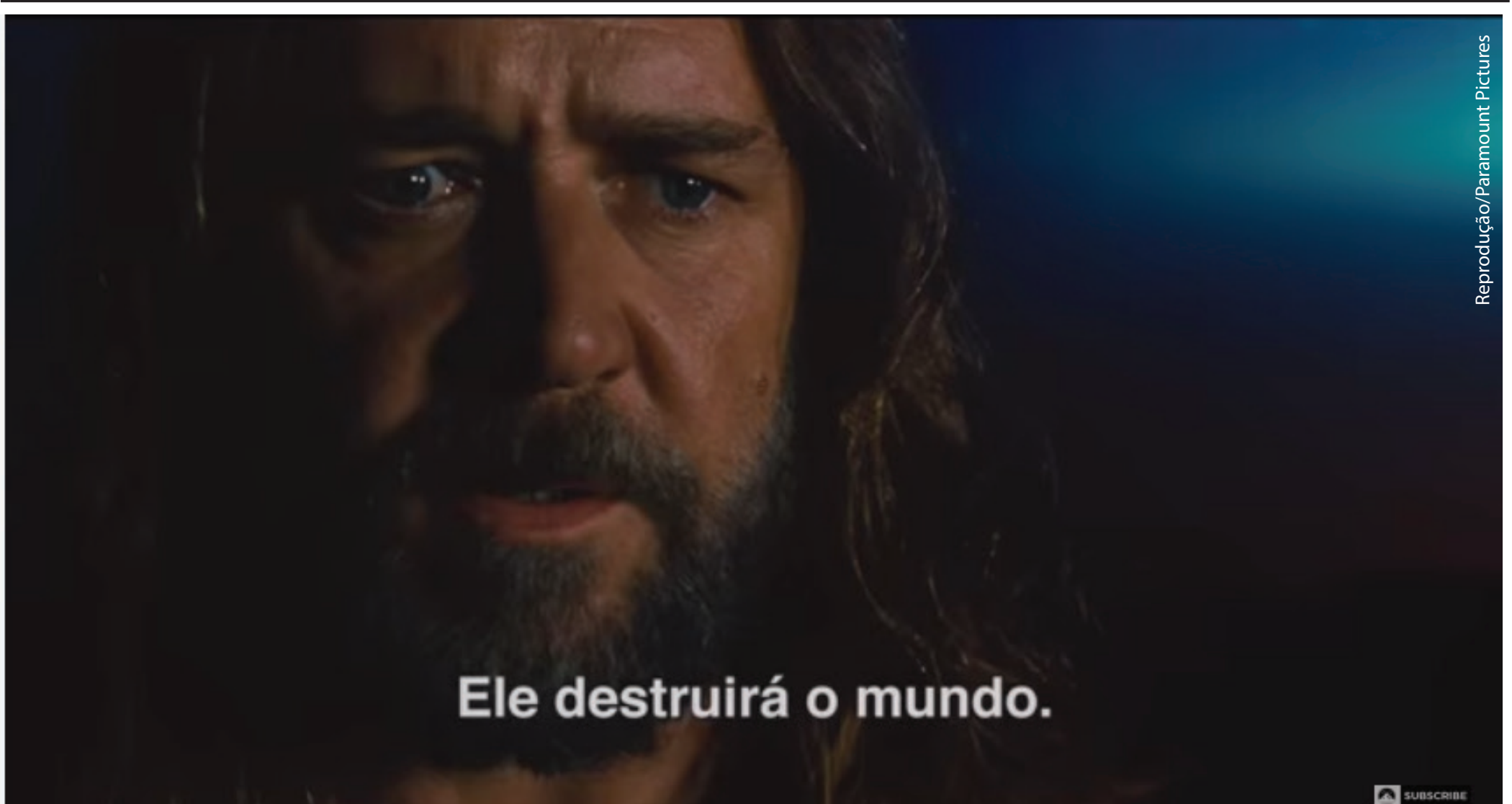

terra firme. Com a decisão de Deus que não seria lançada mais nenhuma maldição sobre a Terra, a história da humanidade volta a ser reconstruída através de Noé e seus descendentes.

\section{Noé - O filme}

Noé (Noah, em inglês) é um filme de gênero épico baseado na história bíblica da Arca de Noé. Noé, sua esposa Namé, e os filhos Cam, Sem e Jafé, vivem em uma terra inóspita, com homens que perseguem e matam uns aos outros sem nenhum temor. Um dia, Noé, em sonhos, tem visões sobre tempestades e so- bre o fim do mundo que se aproxima, e recebe uma mensagem do Criador para que encontre Matusalém, seu pai. Durante o percurso, ele e sua família acabam salvando a vida de uma criança chamada lla, que tem um ferimento grave na barriga e é a única sobrevivente de um vilarejo destruído por malfeitores.

Para encontrar Matusalém, a família terá que passar pela floresta dos gigantes de pedra, seres míticos e avessos aos humanos por questões do passado. Noé e sua família são aprisionados em um grande vale pelas criaturas de pedra. Mas, uma das criaturas vê bondade em Noé e decidi libertá-lo, sem que os demais gigantes 
de pedra saibam. Porém, ao descobrirem, desaprovam a libertação de Noé e seus familiares. Estes gigantes, na lenda fílmica, são anjos caídos que habitavam a Terra. Ou seja, representavam "prisões eternas", pois eram seres de luz antes da criação e foram punidos por tentarem ajudar a humanidade através da transmissão de co-

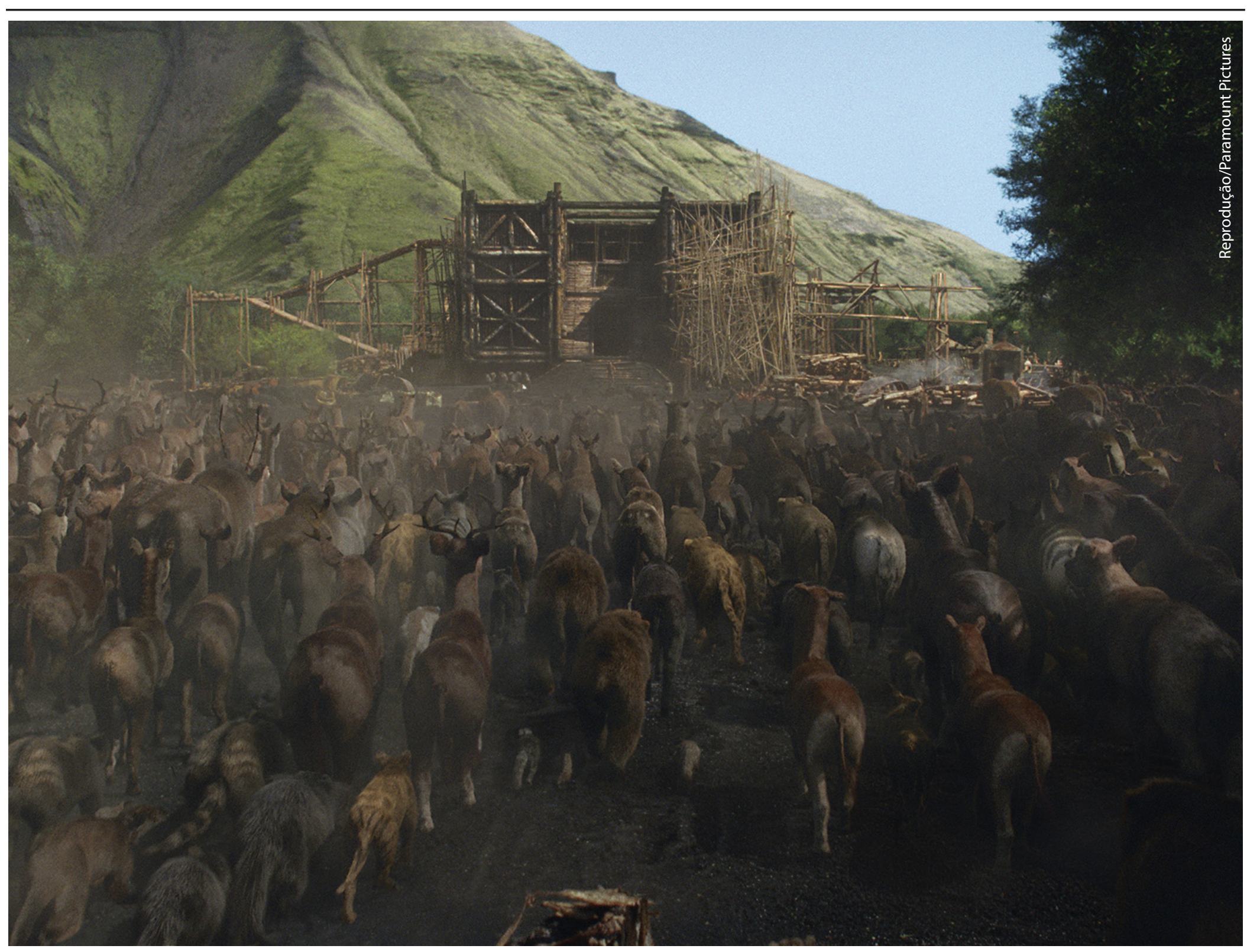
de suas atitudes na Terra, voltar aos céus.

Noé, após todas as adversidades em sua caminhada, encontra Matusalém. $O$ velho profeta lhe diz que ele tem a tarefa de construir uma imensa arca para abrigar os animais durante um dilúvio que acabará com a vida nhecimentos. Entretanto estes poderiam, dependendo na Terra, de forma que a visão do Criador possa ser, enfim, resgatada. E assim, uma floresta cresce em uma velocidade anormal para que toda a matéria-prima necessária fosse disponibilizada a Noé e sua construção. Começa então, a construção da arca, um grande caixote de madeira que deverá abrigar, entre os humanos, um casal de animais de cada espécie. A construção é turbulenta e necessita da proteção dos gigantes de pedra, pois invasores considerados pecadores querem embarcar na arca, atrás da salvação. A arca é para pessoas de coração puro. Noé tem a incumbência de selecionar quem deverá ser salvo. Ao sair disfarçado pelos arredores, ele vai a um acampamento montado próximo à construção da arca. O acampamento é somente para aqueles que conseguirão lutar e se salvar. Em volta do local ficam as crianças, mulheres e os impossibilitados de irem para uma guerra.

Noé vê duas crianças sendo vendidas a troco de carne, pois o alimento no acampamento é escasso. $O$ modo como isso se apresenta choca Noé, que não vê a mínima possibilidade desses homens impuros entrarem na arca. O patriarca, acima de todos, luta consigo mesmo para manter-se fiel ao seu Deus, que ele supõe estar lhe dando uma missão gigantesca e, ao mesmo tempo, proteger sua família e sua linhagem, que vem desde Abel, e que traz em si um paradoxo: ele tem de salvar o planeta do próprio homem, ou seja, dele mesmo. E desta forma, o filme acontece em meio ao caos do dilúvio, e a incerteza de que todos os embarcados sobreviverão, o que de fato ocorre ao final com a chegada a um novo continente, a um novo mundo.

O elemento Fantástico na história sagrada A interpretação de Noé (filme) é livre, de trechos do livro da Gênesis. Noé assume licenças poéticas e não

20 PORTO ALEGRE | v. 19 | n. 32 | 2014 | pp. 18-25 Sessões do Imaginário 
procura ser fiel a fatos históricos ou crenças religiosas. E isso fica exposto em relação ao uso de efeitos sobrenaturais presentes em quase toda a narrativa fílmica. Elementos como criaturas mitológicas, florestas que se autoconstroem e um figurino estilizado, o tornam mais próximo de ficções científicas pós-apocalípticas e fantasias no estilo da trilogia $O$ senhor dos anéis, do que de clássicos bíblicos como Os dez mandamentos (1956) e de outros de mesmo teor. Há uma sensação de estranheza causada pela hibridização tecnológica de imagens.

Pensar o conceito de Sagrado é importante, porque vários cineastas contemporâneos, ao afirmarem-se ateus, não deixam de procurar exprimir o Sagrado ou a espiritualidade em suas obras. Talvez, uma nova tendência do mercado cinematográfico.

Mas, o que é o Sagrado hoje? Definir o Sagrado contemporâneo não é tarefa fácil, depois de uma secularização cada vez mais óbvia das sociedades. No entanto, o sagrado continua a ser procurado e expresso, em particular pela arte. E se o Sagrado está a transformar-se, libertando-se da iconografia tradicional religiosa, ele está presente de forma implícita, em particular no realismo. A forma como alguns cineastas tratam imagens e contextos, permite ao espectador ter a experiência direta e contemporânea do Sagrado.

Será o Sagrado uma força transcendente? Será que hoje a experiência fílmica do Sagrado pode ser feita sem a presença explícita do religioso, levando à criação de uma nova estética cinematográfica? Por exemplo, Noé é um tema sagrado que toca o espectador, mas a expressão transcendente de determinadas criações imagéticas que se manifestam em todos os grandes planos, tornam a exposição das cenas um conjunto de forças que trabalham fantasiosamente com o realismo das emoções, gerando uma apatia fílmica.

21 PORTO ALEGRE | v. 19 | n. 32 | 2014 | pp. 18-25 Sessões do Imaginário
Faz-se necessário pensar que o Sagrado: "é uma 'energia do real' constituído por uma série de pequenas forças que despertam o respeito, a distância, a admiração, a aversão, o medo e muito mais" (Lemos Filho, 1991, p.5).

Contudo, tentar definir o Sagrado apenas pela questão das imagens ou da devoção que se tem a determinados ícones e símbolos é demasiado complexo, porque o Sagrado insere-se em uma estética e em uma ética que podem ser representadas sob vários prismas:

Por outro lado, a noção de sagrado é complexa e ambígua. Existem várias espécies de sagrado na arte do mundo contemporâneo, desde o sagrado estético inerente a toda a obra de arte até o sagrado demoníaco, passando pelo sagrado religioso, o sagrado cósmico, o sagrado maravilhoso, etc. Etienne Souriau distingue vários níveis de existência de uma obra de arte: a existência física que é a obra de arte em seu estado material; a existência fenomenal que é a obra enquanto apresentada aos sentidos, sob a forma de certo jogo de aparências sensíveis; a existência "chosale" enquanto que a obra evoca diretamente (nas artes representativas) e indiretamente (nas artes não representativas) certo número de seres ou de coisas existindo no mundo; e finalmente a existência transcendental, isto é, uma espécie de halo místico que envolve a obra de arte e evoca todo um mundo de idéias e sentimentos e que faz com que a obra tenha certa profundidade. Por isso é dessa transcendência que se fala quando se afirma que toda obra de arte, sob certo aspecto, é sagrada É neces sário, pois, que a perspectiva da obra de arte e a visão do seu autor nos orientem para essa "outra coisa" que nos transtorna totalmente e que per- manece para nós um mistério. Daí a definição de Bazaine: "O sagrado é o sentimento misterioso de uma transcendência brilhando na ordem natural do mundo, no cotidiano" (Lemos Filho, 1991, p. 7).

E, talvez, pelo tema do Sagrado adquirir outras faces que não envolvem somente a questão religiosa, o gênero Fantástico trata de forma diferente a demonstração do sobrenatural. Tem-se aí uma característica antagônica em relação ao elemento maravilhoso, pois neste o universo do maravilhoso fecha-se em si mesmo, é hermético, excludente e, paradoxalmente convencional porque, apesar de erguer-se sobre uma imaginação que subverte os convencionalismos do mundo material e familiar, reafirma a hierarquia do real sobre o irreal. Confirma a impossibilidade de interpenetração entre essas "duas zonas de sentido", como assim designa Irlemar Chiampi (1980, p. 66): o mundo real e o imaginário.

A arbitrariedade com que se dispõem as intervenções mágicas, as metamorfoses e outros fenômenos de caráter extranatural na narrativa do Maravilhoso, assenta, implicitamente, a falsidade e a inexistência do sobrenatural. Já o elemento Fantástico no filme Noé surge em meio a um cenário familiar, tal como ocorre na narrativa, ações próprias de um dia a dia comum, que se reveste de uma característica cotidiana. Tudo parece reproduzir a rotina, a normalidade das experiências conhecidas, quando algo inexplicável e extraordinário rompe a estabilidade deste mundo natural e defronta as personagens com situações inusitadas. A partir disto, a narrativa fantástica confabula com situações racionais e o evento sobrenatural que passa a fazer parte da trama como algo verossímil. Ou seja, o discurso narrativo Fantástico ao mesmo tempo em que constrói a diegese, mantém as personagens num estado de incerteza per- 
Entre o Sagrado e o Fantástico: as (des)construções imagéticas em Noé

manente diante da verdadeira índole dos fenômenos meta-empíricos que cruzam o caminho de suas vidas.

No Fantástico, as personagens oscilam entre uma explicação racional e lógica para os acontecimentos extranaturais - inserindo-os, desta forma, na ordem convencional da natureza - e na admissão da existência de fenômenos que escapam aos pressupostos científicos, racionais e empíricos. Quando surgem os primeiros gigantes de pedra em Noé, acontece o embate entre o que é da ordem do Sagrado e o que é da ordem do Fantástico. Há uma desconstrução de sensações. Apesar de haver a citação na Bíblia sobre estes misteriosos seres, "naqueles dias, havia gigantes sobre a face da terra, pois os filhos de Deus se uniram às filhas dos homens e elas tiveram filhos; estes são os heróis, tão afamados nos tempos antigos" (Gênesis 6,4), opta-se por reproduzi-los tecnologicamente, com características monstruosas e maldosas, no início.

Os gigantes, ou anjos caídos, ao mesmo em que são ou foram seres Sagrados, no contexto também são efeitos especiais imageticamente construídos que vêm, quiçá, a suspender a chamada "suspensão da descrença", pois, em uma história cuja temática é sagrada, homens de pedra são seres fantásticos, tecnológicos, à mercê de uma explicação simulacra.

Todorov (1975) discute a crença na sobrenaturalidade dos fenômenos e a convicção numa explicação que os inscreva num rol de justificativas conformes as leis naturais como o elemento definidor Fantástico. A sobrenaturalidade e o Fantástico caminham em uma mesma mão, são inegáveis sob o ponto de vista do espectador.

Filipe Furtado (1980, p. 95) nos mostra que a posição de Todorov neste ponto revela uma ambiguidade construída pelo discurso fílmico e gera uma condição para o convencimento. $O$ espectador, conduzido pela construção imagética dos gigantes em Noé, desempenha o pa-

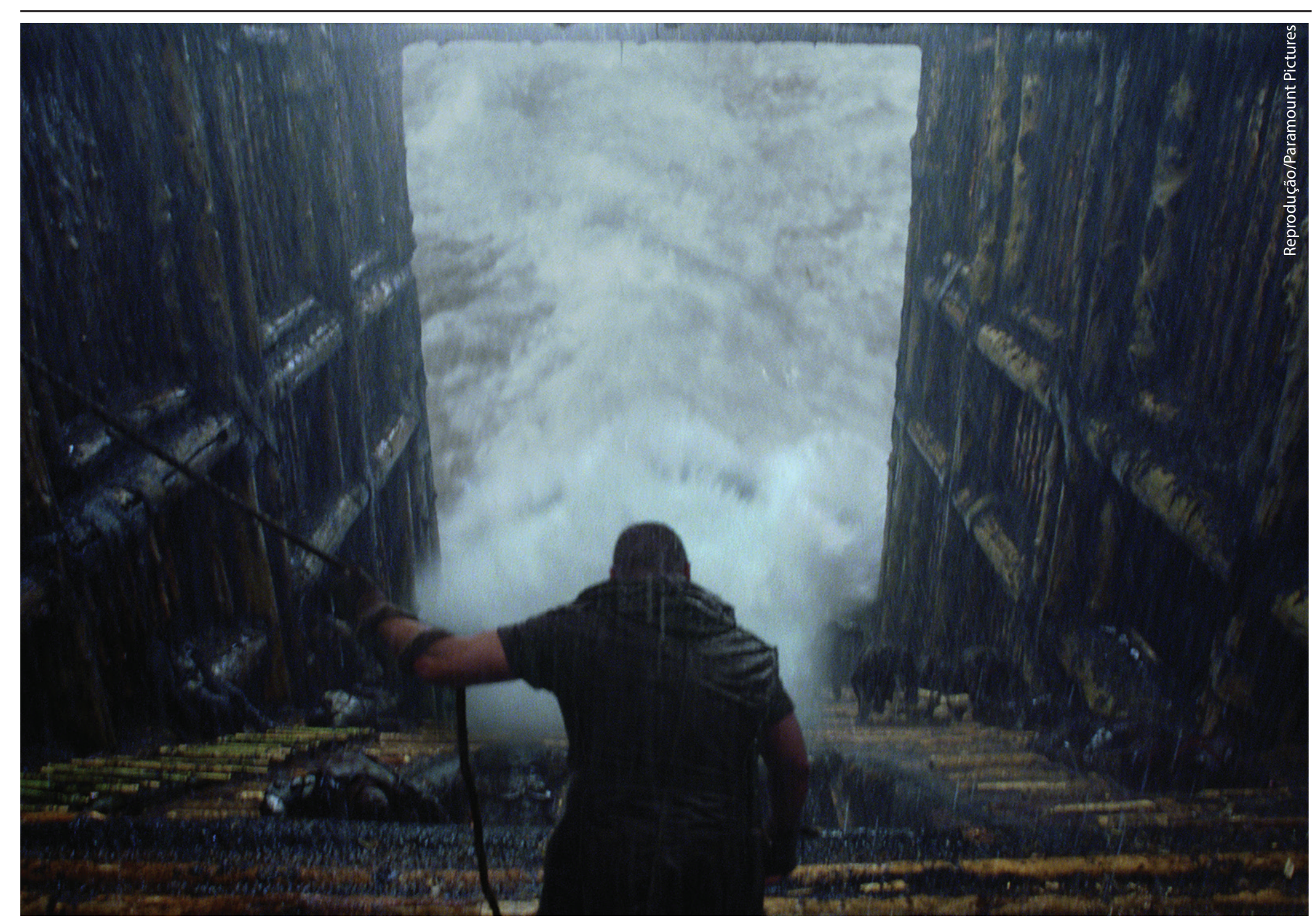

pel de testemunha de acontecimentos Fantásticos que tendem a participar desta construção e identificar-se, até certo ponto, com ela. Mas, segundo Furtado (1980), essa identificação, se não cumprida, não compromete, não obstante, a ambiguidade entre o natural e o sobrenatural comunicada pelo Fantástico. $O$ jogo do discurso verossímil construído e desconstruído sucessivamente neste tipo de filme é assinalado por Furtado (1980) como o grande fator responsável pela eficácia desta ambiguidade que influencia, quase invariavelmente, a percepção do espectador. Assim, para qualquer espectador que conheça a história bíblica sabe de Noé e sua aventura no dilúvio, é quase impossível que prevaleça a ambiguidade nas ações.

Da mesma maneira, os sentimentos de medo, espanto, dúvida, horror, de "estranheza inquietante" (ex-

22 PORTO ALEGRE | v. 19 | n. 32 | 2014 | pp. 18-25 Sessões do Imaginário 
pressão atribuída por Freud aos efeitos da fantasticidade no espírito humano), manifestam a vigência de um tratamento discursivo da narrativa "fantástica", dado aos fenômenos meta-empíricos e aos temas do sobrenatural, que visa à valorização impactante destes fenômenos na consciência seja do espectador ou do leitor. Mas, como estes sentimentos constituem uma característica subjetiva observável, há o "esvaziamento da significação", a perplexidade, o terreno do "não-sentido", e isto se estabelece porque a cisão entre o mundo real e o imaginário apresenta um caráter inconciliável no Fantástico.

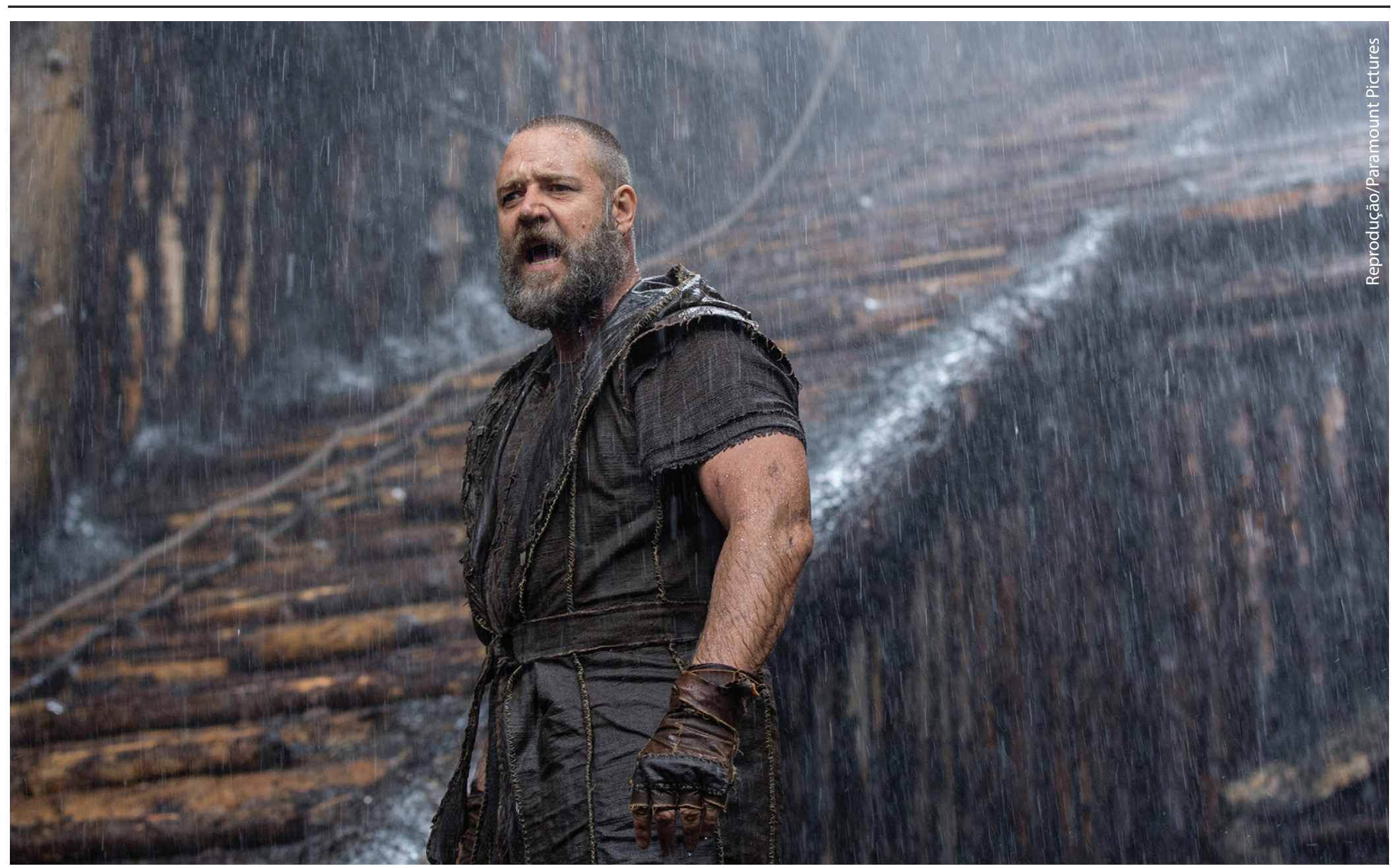

À medida que gigantes de pedra e florestas se tador cria novas perspectivas, novos olhares sobre Noé. Sabe-se que nem na era bíblica tal feito foi "real". E, mesmo aqueles que não conhecem o lado Sagrado, o Noé - personagem bíblico cristão - presenciam o sobrenatural em oposição ao natural, como uma trama de ficção científica que reconstrói a diegese fílmica. A ligação entre o Sagrado e o Fantástico transforma-se em uma ligação híbrida de gêneros. O Fantástico neste contexto é um híbrido. Um constroem digitalmente na trama fílmica, o espec- exemplo alhures para isso seria a trilogia Matrix (The Matrix (1999); The Matrix Reloaded (2003); The Matrix Revolutions (2003)), dos irmãos Wachoswki.

Matrix, simultaneamente, é um filme de ficção científica e uma fantasia gótica acerca de um futuro obscuro para o homem, consequência de suas atitudes passadas. Cada vez mais fazemos parte de um futuro dominado pela tecnologia e pela ciência e, parece que a tônica é, independente do tema, tornar a narrativa hibridizada para uma saída dos lugares comuns das narrativas pouco empolgantes. Em Noé, a inserção dos gigantes de pedra, da floresta visivelmente construída por computação gráfica, além de outros elementos, como as cores monocromáticas dos animais tornam a obra reconhecida mais pelos efeitos sensoriais tecnológicos que despertam no espectador, do que por sua sagracidade.

Assim, o Fantástico e o humano em Noé, no centro da existência, modifica a noção de pecado e castigo e faz transitar do real (a Bíblia) para o Fantástico qualquer manifestação de sobrenatural. Com a secularização progressiva da sociedade, a capacidade de suscitar a crença depende de uma opção voluntária do espectador no sentido da rendição à trama, de estar ligado a uma suspensão do descrédito perante elementos que são, mais do que nunca, percepcionadas como artificiais ou irreais no século $X X$ pelo espectador.

Filipe Furtado, em seu estudo $A$ Construção do Fantástico na Narrativa (1980), obriga-nos à readequação de alguns artifícios sobrenaturais. Às manifestações sobrenaturais de natureza supersticiosa sobrepõem-se as que partem do homem. Reflexos em espelhos e outras superfícies, desdobramentos no espaço e no tempo, sonhos e visões, que podem tomar a forma de assombrações, duplos ou gêmeos,

23 PORTO ALEGRE | v. 19 | n. 32 | 2014 | pp. 18-25 Sessões do Imaginário 
esquizofrenias, bipolaridades e outras perturbações mentais, contrastes (interior e exterior, luz e sombra, bem e mal, entre muitos outros) têm na sua gênese os desfasamentos internos das personagens, que se expressam, frequentemente, através de sinais exteriores de monstruosidade física ou comportamental. Talvez isso seja o que acomete o personagem Noé, pois quando se vê entre os que devem ser salvos em sua arca e os que devem ficar e morrer no dilúvio, seu juízo de valor não o permite diferenciar os inocentes dos nóxios ao mundo, e assim, o seu lado mau acaba prevalecendo.

Isso fez com que sua bondade, no estudo da tradição religiosa, fosse questionada. Será que Noé era o único homem virtuoso em uma humanidade má? Não vamos nos ater a tal questionamento, pois esse não é o escopo do trabalho, mas serve como pano de fundo para a construção de toda a narrativa fílmica que aqui se apresenta. São pelas ações de Noé que o Fantástico adquire forma e intensifica as ações sagradas, ou "benevolentes". Ou, talvez, deixe o conceito do Sagrado mais estilizado, mais voltado às tendências do cinema do século XXI: impactante tecnologicamente.

Chiampi (1980), na obra O Realismo Maravilhoso, observa que o discurso do Fantástico encontra esta forma de ressonância no espírito humano em função da presença, fundamentada social, cultural e historicamente, de um medo inconsciente, atávico, do desconhecido. A forma "fantástica" garante o despertar destes sentimentos porque projeta imagens e uma atmosfera particular, ligadas a estados mórbidos da consciência.

As emoções de medo ou horror, bem como a sensação de nojo dos seres ameaçadores ou monstruosos glorificam uma concepção maniqueísta do mundo: o Bom, o Bem, O São e o Divino saem vencedores no conflito. A problematização do real no fantástico assume, neste sentido, o caráter de uma luta primordial entre forças antagônicas, da qual saem vitoriosos os valores que o pensamento logocêntrico aceita como positivos (Chiampi, 1980, p. 67).

Segundo Silvio Zamboni (1998) em A pesquisa em arte: um paralelo entre arte e ciência, toda tecnologia empregada em um filme cuja história liga-se ao Sagrado também terá uma relação íntima com a produção de arte, com a técnica que procura tornar a obra única, revisitada, talvez, para se contar uma história tradicional sob o olhar de outra técnica, que podemos entender neste aspecto como o Fantástico na narrativa. Para Zamboni, vídeos e computadores criam novas possibilidades de imagens:

As tecnologias foram e continuam sendo ferramentas com que o artista passa a contar para a expressão e a comunicação de suas idéias. Elas, per si, não criam idéias novas e revolucionárias, mas servem para criar novas perspectivas dentro do mesmo paradigma, do mesmo conjunto de ideias já estabelecido. [...] A tecnologia pode recriar e refazer o que não foi feito, seu uso é valioso em qualquer paradigma, porém sendo ferramenta e não idéia, nunca por si mudará o paradigma em que está atuando (Zamboni, 1998, p.42).

Outra característica considerável quando se realizam adaptações baseadas em obras literárias ou bíblicas é a de se manter a sua inteligibilidade, mesmo quando a ela se incorporam criações sobrenaturais, fantásticas que possibilitam outras análises de seus espectadores.

A dificuldade das adaptações reside na necessidade de tornar a narrativa perfeitamente inteligível à primeira vista (ao contrário do leitor de romance, o espectador não pode voltar atrás, apesar de poder - e não deve deixar de fazê-lo quando se trata de obras-primas - ver um filme várias vezes, quando captará todos os aspectos, todas as sutilezas que Ihe escaparam nas projeções precedentes). Além disso, há o problema de "temporalidade": é importante reunir o máximo de coisas num mínimo de tempo, exprimir tudo pela ação num tempo limitado; donde a necessidade de estilizar, de suprimir uma grande parte dos elementos do romance que se está adaptando para conservar somente o essencial da ação, o que existe de mais significativo nas individualidades. [...] Dadas as diferenças fundamentais entre os meios de expressão da literatura e do cinema, a adaptação mais escrupulosa é necessariamente a passagem de uma linguagem a outra, é uma tradução e, portanto, "uma traição criativa", segundo Robert Escarpit (Betton, 1987, p.117).

O espectador gosta de manter uma relação harmoniosa, seja com suas ideias, seja com sua forma de pensar, e principalmente com aquilo que lhe é exposto; ele gosta de saber, metaforicamente, "em qual terreno está pisando", portanto o acréscimo de elementos estranhos às condições que lhe são "normais", cotidianas, pode gerar-Ihe frustração, desinteresse, assim "chocado por uma obra, por uma imagem ou pensamento, o 'receptor' nem sempre tem o espírito suficientemente aberto para dizer: 
Entre o Sagrado e o Fantástico: as (des)construções imagéticas em Noé

'o filme é bom, bem interpretado, embora me choque'"' (Betton, 1987, p.89). Talvez Noé seja isso - um estranho.

\section{Conclusão}

Os efeitos de sentido causados em Noé são da ordem do Fantástico, do sobrenatural lúdico, em que o Sagrado, a essência norteadora da construção fílmica aqui, fica a cumprir a missão de descrever os fatos dentro de uma estética hollywoodiana de adaptar para o cinema um material que já tenha base sólida de "fãs", na tentativa, quem sabe, de garantir retorno de bilheteria.

Outra vantagem bem vista é que usar a Bíblia como fonte não requer pagamento de direitos autorais. $E$ ainda, usar a Bíblia com alta tecnologia é um princípio, quiçá, da construção de novos filmes de ficção científica com base religiosa. Noé é bíblico, sua missão sagrada foi conhecida mundialmente por aqueles que se interessam pelo assunto, e revisitá-la com homens fantásticos que se formam de pedras, ou florestas que se proliferam na velocidade da luz é trabalhar com o lado consciente do espectador. Se uma das principais características do cinema é a "suspensão da descrença", o filme Noé não nos coloca em um universo diegético programado para uma imersão audiovisual, para um sonhar acordado, mas para uma ruptura com que se pretende encontrar neste discurso fílmico, e a cada nova cena de efeitos especiais vem à tona não a "suspensão da descrença", mas a "encenação da crença".

\section{Referências}

A Bíblia Sagrada: tradução na linguagem de hoje. São Paulo: Sociedade Bíblica do Brasil, 2000.

BETTON, Gerard. Estética do cinema. São Paulo: Martins Fontes, 1987
CHIAMPI, Irlemar. 0 realismo maravilhoso. São Paulo: Perspectiva, 1980

FURTADO, Filipe. A construção do fantástico na narrativa. Lisboa: Horizonte Universitário, 1980.

LEMOS FILHO, Arnaldo. O cinema e o sagrado. 2a parte. Comunicarte, Campinas, n.14, 1991.

TODOROV, Tzvetan. Introdução à literatura fantástica. São Paulo: Editora Perspectiva, 1975.

ZAMBONI, Silvio. A pesquisa em arte - Um paralelo entre arte e ciência. Campinas: Autores Associados, 1998.

\section{Referências audiovisuais}

ARONOFSKY, Darren. Noé (Noah). [Filme-vídeo]. Direção de Darren Aronofsky. Estados Unidos, 2014. 138min. color. son.

WACHOWSKI, Lana; WACHOWSKI, Andy. Matrix. [Filme-vídeo]. Direção de Lana Wachowski e Andy Wachowski. Estados Unidos, 1999. 135min. color. son.

\section{Notas}

1 Trabalho apresentado originalmente no XXXVII Congresso Brasileiro de Ciências da Comunicação.

2 Doutoranda em Comunicação e Linguagens pela Universidade Tuiuti do Paraná e docente na Pontifícia Universidade Católica do Paraná (PUCPR - Rua Imaculada Conceição, 1.155 - Prado Velho, CEP: 80215-901, Curitiba/PR, Brasil). E-mail: farodri@gmail.com. 